International Journal of Engineering \& Technology, $7(2.6)(2018) 323-326$
International Journal of Engineering \& Technology
SPC
Website: www.sciencepubco.com/index.php/IJET
Research Paper

\title{
Inflated Portable Cold Storage House with Solar Cells as facilities to support the fisheries production and marketing
}

\author{
M Ikhsan Setiawan ${ }^{1 *}$, Iswachyu Dhaniari², Cholil Hasyim ${ }^{3}$, Yuniningsih ${ }^{4}$, Dahlan Abdullah $^{5}$, \\ Veronika Nugraheni Sri Lestari ${ }^{6}$, Wahyu Mulyo Utomo ${ }^{7}$, Agus Sukoco ${ }^{8}$, Sri Wiwoho Mudjanarko', \\ Arasy Alimudin ${ }^{8}$, Dani Harmanto9 and Ansari Saleh Ahmar ${ }^{10}$ \\ ${ }^{1}$ Department of Civil Engineering, Narotama University, Surabaya, Jawa Timur 60117, Indonesia \\ ${ }^{2}$ Department of Law, Narotama University, Surabaya, Jawa Timur 60117, Indonesia \\ ${ }^{3}$ Department of Management, Darul Ulum University, Jombang, Jawa Timur 61419, Indonesia \\ ${ }^{4}$ Department of Management, Universitas Pembangunan Nasional Veteran Jawa Timur, Surabaya, Jawa Timur 60294, Indonesia \\ ${ }^{5}$ Department of Informatics, Malikussaleh University, Lancang Garam, Aceh Utara 24351, Indonesia \\ ${ }^{6}$ Department of Management, Dr. Soetomo University, Surabaya, Jawa Timur 60119, Indonesia \\ ${ }^{7}$ Department of Informatics, Narotama University, Surabaya, Jawa Timur 60117, Indonesia \\ ${ }^{8}$ Department of Management, Narotama University, Surabaya, Jawa Timur 60117, Indonesia \\ ${ }^{9}$ University of Derby, School of Technology, Derby, United Kingdom \\ ${ }^{10}$ Department of Statistics, Universitas Negeri Makassar, Indonesia \\ *Corresponding author E-mail: ikhsan.setiawan@narotama.ac.id
}

\begin{abstract}
The global fish production currently reaches 158 million tons to 91.3 million tons. However the largest contribution is provided by the fisheries sector. An estimated 136.2 million tons of fish are used directly for consumption and then for fish and livestock. In the fishery sector, Indonesia was ranked second after China, while in the fish cultivation sector Indonesia was ranked fourth after China, India, and Vietnam. The result of increasing exports reached 35.4 billion dollars in 2012. The Technology Inflated Portable Cold Storage House with Solar Power as facilities to support fisheries production and marketing, can be built and applied in a residential location/ specific housing easily, safely, quickly and lightly $(0,55 \mathrm{~mm}$ PVC Tarpaulin). The development program of this technology in supporting fisheries production and marketing meet the requirements of strength, speed, flexibility and comfort. This technology also increased the absorption of the National Fish stock. Specific targets on this research is to provide Cold Storage House Prototype with solar in supporting fisheries production and marketing with cheap and profitable so that can be mass-produced. This research used experiments and action research. The process of research is starting with the development of the design, manufacture, testing and repair of Inflated Portable Cold Storage House with Solar Power Prototype, included first, a technical test of strength and endurance of Portable inflated Structure materials to the weather; second, testing the speed of the manufacture, transportation, assembly, installation, disassembly of Portable Inflated Structure; third, testing temperature, humidity and air pressure in the Inflated Portable Cold Storage House with Solar Power; fourth a technical test, related to the fishery from frozen and market in Inflated Portable Cold Storage House with Solar Power in order to obtain hygienic, inexpensive and profitable fisheries.
\end{abstract}

Keywords: Fish Production, Fisheries, Portable Cold Storage, Solarcells, Technology Inflated House.

\section{Introduction}

Indonesia consists of 17,502 islands and a coastline of $81,000 \mathrm{~km}$ with a total area of fishing in the sea about 5.8 million $\mathrm{km}^{2}$. It consists of the archipelagic waters. Its territorial area is 3.1 million $\mathrm{km}^{2}$ while the Exclusive Economic Zone waters of Indonesia (ZEEI) area is 2.7 million $\mathrm{km}^{2}$. Moreover, the fish resources have the highest level of biodiversity (bio-diversity). It covers $37 \%$ of fish species in the world. There are several types of fish of high economic value such as: tuna, yellowfin tuna, shrimp, tuna, mackerel, snapper, squid, reef fish such as grouper, baronang, barong shrimp / lobster. The potential of fishery resources is estimated to reach 6.4 million tons per year with the current utilization potential of $80 \%$ or 5.12 million tons per year. Ministry of Maritime Affairs and Fisheries estimates Indonesia's fishery production will reach 7 million tons by the end of 2015, there will be a growth of $16.7 \%$ compared with the realization of catching fish production in 2014 amounted to 6 million tons and 8 million tons in 2016, or increased $14.3 \%$ compared to 2015. Buying and selling transactions of marine products such as fish is usually done at the fish auction market (TPI) that located at the port or on the fish landing-bridge. TPI is managed by local government, cooperatives or private parties. In 2015 there are 411 TPI operating in Indonesia. Marine products offered include all types of fish or other sea animals produced by fishermen. There are 36 types of fish and some types of shrimp such as barong shrimp, tiger prawns, jerbung shrimp, and shrimp windo, shrimp rebon, potential in Indonesia. Indonesia Fishery Production in 2013-2015 can be seen in Table 1. In 2015 fishery production reaches 5,357,120 q. Compared to previous year, total fishery production in TPI has decreased to $13.75 \%$, where the total production in the previous year was $6,210,991$ q. The largest production decline in 2014 was in 
the second quarter that reached $23.32 \%$ of production or from $1,638,996 \mathrm{kw}$ to $1,256,795 \mathrm{kw}$. The next largest production decline was in the third quarter that reached $20.76 \%$ and the fourth quarter only $12.92 \%$. The largest marine fish production was located in Java with production $3,703,395 \mathrm{kw}$ or about $69,13 \%$, while outside Java region contributed about $30,87 \%$ with production $1,653,725 \mathrm{kw}$. The highest fish sales in 2015 were in the fourth quarter with production of $1,520,045 \mathrm{kw}$, followed by the first and third quarters with respectively production of $1,317,731$ $\mathrm{kw}$ and $1,262,549 \mathrm{kw}$, while fish production was the lowest in the second quarter around 1,256,795 $\mathrm{kw}$. The average production of marine fish sold in each TPI reached $2,861 \mathrm{q}$ in the first quarter, $3,776 \mathrm{q}$ in the second quarter, 3,714 $\mathrm{q}$ in third quarter and 4,136 $\mathrm{q}$ in the fourth quarter with the highest increase in the fourth quarter. When compared with regions, the highest average fish sales were in Maluku and Papua with average daily fish sales reached 21,761 kw per TPI, Bali and Nusa Tenggara were in second position with average sales of 14,009 kw per TPI, followed by Java with an average of $4.826 \mathrm{kw}$ also in the fourth quarter, and the Sumatran region occupies the fourth position with an average sales of 4,331 kw per TPI in the first quarter. The fifth position is managed by Kalimantan with average sales of fish production of $3178 \mathrm{kw}$ per TPI. The last is Sulawesi sales an average of $2455 \mathrm{kw}$ per TPI in the third quarter. In 2015, fish production sales in TPI averaging over $20 \%$ in each quarter, the largest percentage in the fourth quarter which was the peak period of fish sales at TPI. In this quarter marine fish production sold in TPI reached $28.72 \%$. While production in the first quarter reached $27.66 \%$; third quarter of $22.14 \%$; and the first quarter reached $21.48 \%$. Regionally, peak sales season varies considerably, in Java, Bali and Nusa Tenggara, Kalimantan, Maluku and Papua reaching peak sales in the fourth quarter respectively of $31.15 \%, 40.54 \%, 39.05 \%$ and $25 \%$. The highest sales peak was in Sumatra in the first quarter with sales percentage reaching $58.17 \%$, while for Sulawesi region peak sales occurred in the third quarter that reached $29.68 \%$. Percentage of marine fish production based on fish type. As in the previous description, the types of fish presented in this paper consist of 36 species of fish potential in Indonesia. Those types of fish contribute greatly to the total production and it can be used as to describe the potential of a region. Fish species that sold in TPI in each region is varied, not specific to one or two fish species. Nationally, sharks provide the largest contribution to the percentage of sales in 2015 that reached $58.13 \%$ of total fish sales. The biggest contributor to shark sales was in Java with sales percentage reached $66.75 \%$. Other major fish species in the national sales are Scad $(5.66 \%)$, long tuna $(4.27 \%)$, skipjack tuna $(2.05 \%)$, and mackerel $(1.36 \%)$. Unlike the sharks dominated by Java, the last four fish species are spread almost evenly throughout Indonesia [1]-[3]

\section{Experimental Details}

The facilities of treatment and preserving fishery production, especially in the freezing process could increase the economic value, which could be enjoyed by the fisheries business in the area, such as stabilizing commodity prices fishery as well as a contributor to the reduction of unemployment through the absorption of labor. Operation cold storage can create various employment opportunities such as traders, laborers and employees. Cold Storage is one of the supporting tools that serves as a shelter for marine products to maintain its quality until distributed to consumers. Cold Storage plays an important role in keeping the selling price of marine products stable when the fisherman's yield decreases. Research and testing of pneumatic system structures such as pneumatic structure test models have been conducted in a study entitled "Study of Pneumatic Structures and Design" with case studies on Single Pneumatic Roof Membrane Structures in the Gymnasium in 1992. This research mentions that pneumatic structure has several advantages compared to conventional building structure, that is requires only a small initial investment, speed and ease of development, ease of maintenance, structural elements can be folded quickly so that it can be stored in an area of $3 \times 3 \mathrm{~m}^{2}$. Advanced research was done in 2008-2010 through the Higher Research Grant of Higher Education of Indonesia. This research produced air-fired pneumatic prototype. This prototype can be done just in 30 minutes. The building area needed to accommodate 50 people is $150 \mathrm{~m}^{2}$. The downside of this prototype is the use of an airtight rigid door where people will be hard to get out of the tent bubbles. Setting-Up Process of Inflated Portable Structure and Finishing Build-Up of Inflated Portable Structure are shown in Figure 1 and Figure 2 respectively. Purwanto's research shows the possibility of applying and developing pneumatic structures in Indonesia that are faced with the problem of climatic conditions, especially wind problems. Thus we must pay attention to social behavior and conditions. People should be awared on the maintenance and avoided vandalism of buildings or public facilities. Alain Chassagnoux et al explains that study the contemporary architecture using nonconventional structures can be done by conducting mathematical structural design experiments through geometry and science studies. Inflated Portable Cold Storage House with Solar Cell with Portable Structure technology meets the requirements on strength, comfort and durability. Portable Inflatable Membrane Material Structures are weather resistant for up to 10 years, depending on the type of coating material. In addition, the membrane material proved to be reliable. Based on laboratory and field tests, the Inflated Portable Cold Storage House with Solar Cell provides satisfactory results up to $218.3 \mathrm{~kg}$, the durability of the material of $>$ 700C, 3 minutes installation, and indoor temperature <350C. Portable inflated Structure is removable and folded so it can be used in a confined area with lightweight structural materials $(0.55 \mathrm{~mm}$ PVC Tarpaulin) and moved to another location by truck / pickup. The policy of limiting marine products below 10 GT (Gross Ton) has made fishermen increase their production. The abundance of marine products raises fears of loss to fishermen, however with abundant sea produce will automatically impacting the fall in fish prices. Thus, fishermen need fish cold storage that keeps fish fresh. Cold Storage can be a solution in maintaining the quality of fish or other marine products. In other hand, cold storage needs cost and there are limited energy resources, then the many fishing shelters does not have Cold Storage. The solution offered to fishermen is Cold Storage Technology at a low cost, namely Inflated Portable Cold Storage House with Solar Cell. Inflated Portable Cold Storage Houses with Solar Cells must meet the requirements of convenience and duration of Cold Storage placement in shelters, removable, folded and moved to other locations only by truck or pickup [4]-[12].

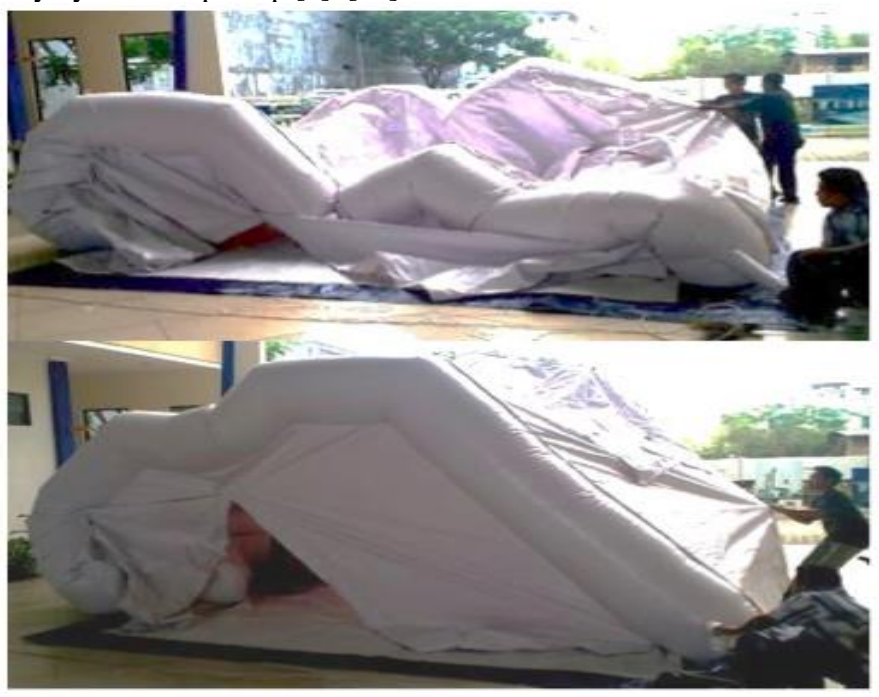

Fig. 1. Setting-Up Process of Inflated Portable Structure 

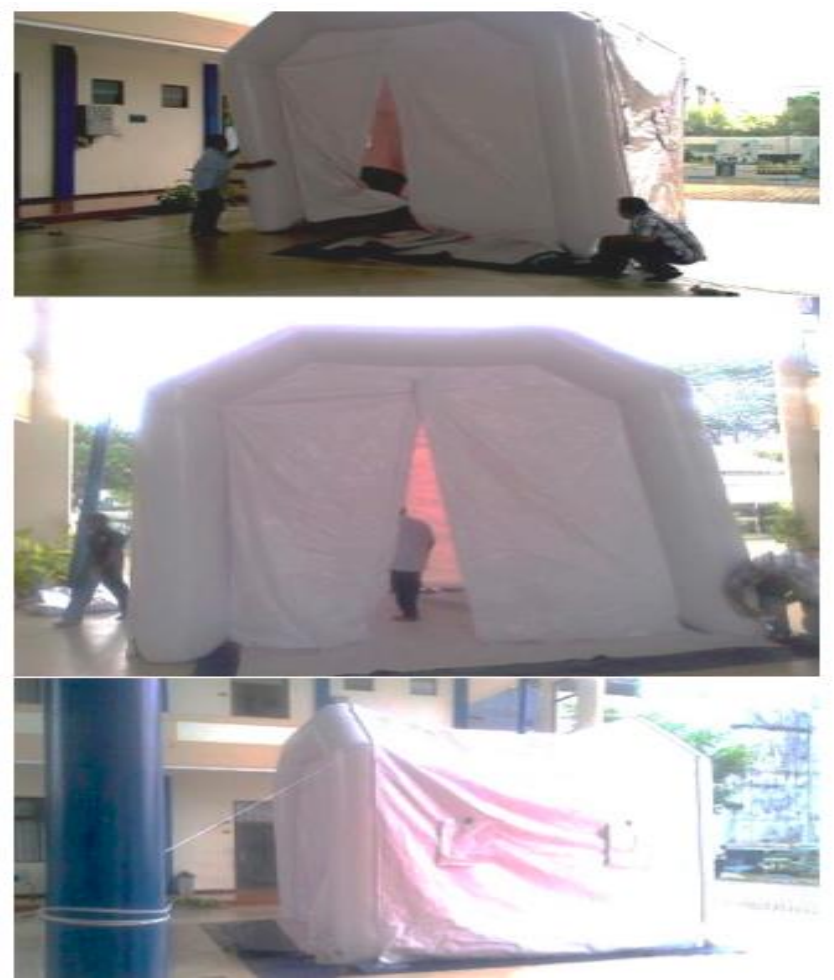

Fig. 2. Finishing Build-Up of Inflated Portable Structure

\section{Results and Discussion}

The availability of Inflated Portable Cold Storage House technology Prototype with Solar Cell which has speed and effectiveness in the process of transportation, assembly, installation, dismantling, tested thermal comfort (temperature, humidity and air pressure) and tested in Lab and Field is needed for Fisherman.

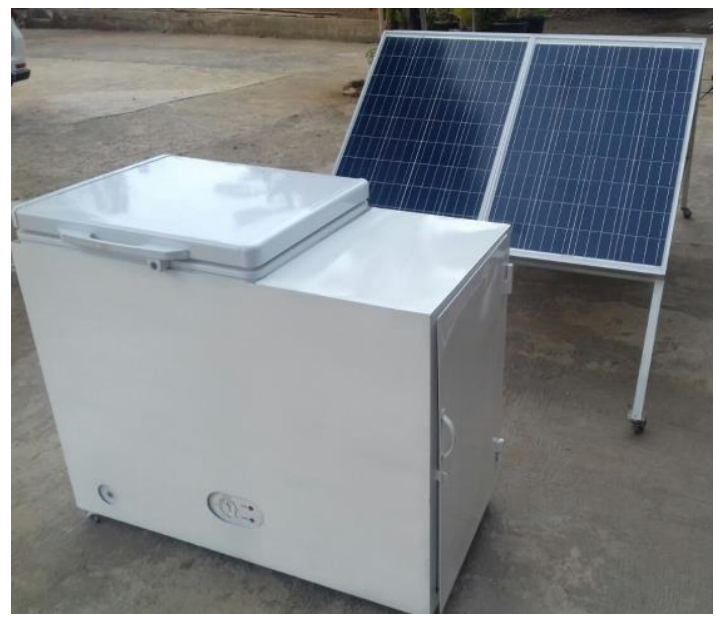

Fig. 3. Cold Storage Solar Cell for fisherman

Availability of Inflated Portable Cold Storage House technology prototype with Solar Cell can be mass produced by Industry Partners that can help accelerate the marketing of hygienic, cheap and profitable fish nationally. Indonesia is one of the key players in global fisheries. In the fishery sector, Indonesia ranked second after China and for fish cultivation, Indonesia ranked fourth after China, India and Vietnam. In terms of foreign exchange earnings, export results of Indonesian fishery products has increased to US \$ 35.4 billion in 2012. Inflated Portable Cold Storage House with Solar Cell product can meet the requirements of strength, speed and comfort in the open area. Inflated Portable Cold Storage House Technology with Solar Cell is a solution to keep fresh fish availability by keeping the city clean, cheap and profitable.
Placement Inflated Portable Cold Storage House is flexible, it can be in residence / housing so it can be applied to the urban community. Technology of Inflated Portable Cold Storage House with Solar Cell has high prospects for mass-manufactured by Industrial Partners, due to the high demand for fresh fish urban and inadequate availability of hygienic fish production, but cheaper.

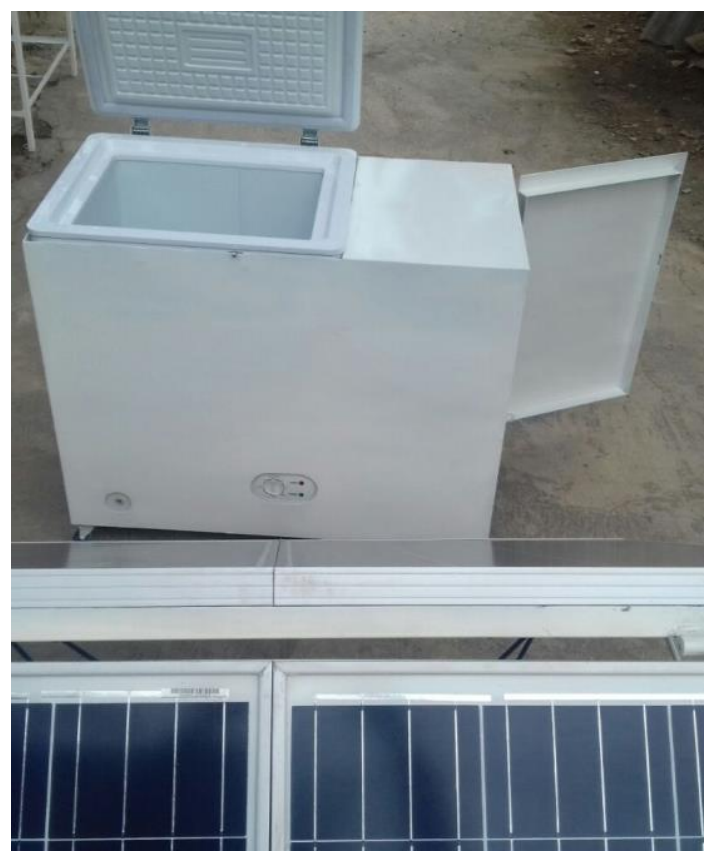

Fig. 4. Cold Storage Solar Cell Details for fisherman

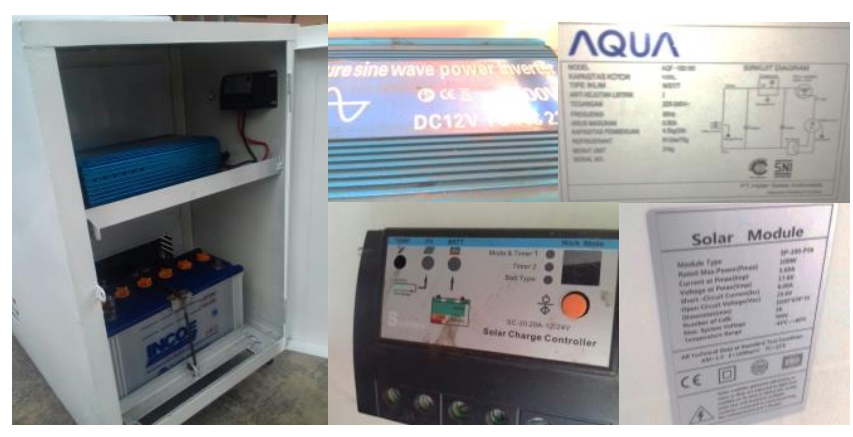

Fig. 5. Cold Storage Solar Cell specification for fisherman

\section{Conclusions}

The global fish production currently reaches 158 million tons to 91.3 million tons. However the largest contribution is provided by the fisheries sector. An estimated 136.2 million tons of fish are used directly for consumption and then for fish and livestock. In the fishery sector, Indonesia was ranked second after China, while in the fish cultivation sector Indonesia was ranked fourth after China, India, and Vietnam. The result of increasing exports reached 35.4 billion dollars in 2012. The Technology Inflated Portable Cold Storage House with Solar Power as facilities to support fisheries production and marketing, can be built and applied in a residential location/ specific housing easily, safely, quickly and lightly $(0,55 \mathrm{~mm}$ PVC Tarpaulin). The development program of this technology in supporting fisheries production and marketing meet the requirements of strength, speed, flexibility and comfort.

\section{Acknowledgement}

This paper is a part of Indonesian Ministry of Research, Technology, and Higher Education's Research Grants. 


\section{References}

[1] BPS, profil pelabuhan perikanan 2013-2015. BPS statistics indonesia, 2016

[2] BPS, Produksi Ikan Laut yang dijual di Tempat Pelelangan Ikan 2015. 2016.

[3] BPS, Tinjauan Regional berdasarkan PDRB Kabupaten/Kota tahun 2011-2015 pulau Nusa Tenggara, Maluku dan Papua, Buku 5. Badan Pusat Statistik, 2016.

[4] J. Suyono, A. Sukoco, M. I. Setiawan, Suhermin, and R. Rahim, "Impact of GDP Information Technology in Developing of Regional Central Business (Case 50 Airports IT City Development in Indonesia)," IOP Conf. Ser. J. Phys. Conf. Ser., vol. 930, p. 11002, 2017.

[5] Ratnadewi, R. P. Adhie, Y. Hutama, A. S. Ahmar, and M. I. Setiawan, "Implementation Cryptography Data Encryption Standard (DES) and Triple Data Encryption Standard (3DES) Method in Communication System Based Near Field Communication (NFC)," J. Phys. Conf. Ser., vol. 954, no. 1, p 12009, 2018.

[6] Y. Hanun, M. I. Setiawan, N. Kurniasih, C. Hasyim, and A. S. Ahmar, "Airport Performance and Construction Enlargement Activities," J. Phys. Conf. Ser., vol. 954, no. 1, p. 12016, 2018.

[7] Sabib, M. I. Setiawan, N. Kurniasih, A. S. Ahmar, and C. Hasyim, "Pavement Technology and Airport Infrastructure Expansion Impact,” J. Phys. Conf. Ser., vol. 954, no. 1, p. 12017 , 2018.

[8] N. Kurniasih, C. Hasyim, A. Wulandari, M. I. Setiawan, and A S. Ahmar, "Comparative Case Studies on Indonesian Higher Education Rankings," J. Phys. Conf. Ser., vol. 954, no. 1, p. 12021, 2018.

[9] T. D. Laksono, N. Kurniasih, C. Hasyim, M. I. Setiawan, and A S. Ahmar, "The Impact of Airport Performance towards Construction and Infrastructure Expansion in Indonesia," J. Phys. Conf. Ser., vol. 954, no. 1, p. 12015, 2018

[10] D. Napitupulu, R. Rahim, D. Abdullah, M. I. Setiawan, L. A. Abdillah, A. S. Ahmar, J. Simarmata, R. Hidayat, H. Nurdiyanto, and A. Pranolo, "Analysis of Student Satisfaction Toward Quality of Service Facility," J. Phys. Conf. Ser., vol. 954, no. 1, p. 12019, 2018

[11] M. I. Setiawan, S. Surjokusumo, D. M. Ma'soem, J. Johan, C. Hasyim, N. Kurniasih, A. Sukoco, I. Dhaniarti, J. Suyono, I. N. Sudapet, R. D. Nasihien, S. W. Mudjanarko, A. Wulandari, A. S. Ahmar, and M. B. N. Wajdi, "Business Centre Development Model of Airport Area in Supporting Airport Sustainability in Indonesia," J. Phys. Conf. Ser., vol. 954, no. 1, p. 12024, 2018.

[12] A. S. Ahmar, N. Kurniasih, D. E. Irawan, D. U. Sutiksno, D Napitupulu, M. I. Setiawan, J. Simarmata, R. Hidayat, Busro, D. Abdullah, R. Rahim and J. Abraham, “Lecturers' Understanding on Indexing Databases of SINTA, DOAJ, Google Scholar, SCOPUS, and Web of Science: A Study of Indonesians," J. Phys. Conf. Ser., vol. 954, no. 1, p. 12026, 2018 